\title{
ISLAMISASI ILMU PENGETAHUAN KONTRIBUSI DALAMI MENGATASI KRISIS MASYARAKAT MODERN
}

\author{
B. Marjani Alwi \\ Fakultas Tarbiyah dan Keguruan \\ Universitas Islam Negeri Alauddin Makassar \\ Jl. H. M. Yasin Limpo No. 36 Samata, Gowa \\ Email: marjanialwi@yahoo.com
}

\begin{abstract}
Abstrack: Islamization of science is an attempt to find the root of the problem from the consequences of the concept of dichotomy between religion and science that can be said to be contradictory. Religion assumes or sees a problem from a normative point, whereas science views it from an objective point of view that then becomes one of the causes of the emergence of the crisis of modern society.
\end{abstract}

Keywords: Islamization of science, Crisis of modern society.

\section{PENDAHULUAN}

\section{A. Latar Belakang Masalah}

uatu kenyataan dalam dunia modern ialah adanya kontradiksi yang mengganggu N kebahagiaan seseorang dalam hidupnya. Pada dasarnya, kemajuan industri telah dapat menghasilkan alat yang memudahkan dan membawa kebahagiaan dalam kehidupan seseorang, sehingga kebutuhan jasmani tidak sulit lagi untuk dipenuhi. Pada kenyataannya, bahwa kebahagiaan itu ternyata semakin jauh, hidup semakin sulit dan kesulitan material berganti dengan kesulitan mental. Beban jiwa semakin berat, kegelisahan dan tekanan batin lebih sering terjadi dan lebih menekan sehingga mengurangi kebahagiaan. ${ }^{1}$

Ilmu pengetahuan merupakan salah satu media untuk mencapai kehidupan yang lebih baik Selanjutnya, masyarakat modern telah berhasil mengembangkan ilmu pengetahuan dan teknologi canggih untuk mengatasi berbagai masalah kehidupan, namun di sisi lain ilmu pengetahuan dan teknologi canggih tersebut tidak mampu menumbuhkan moralitas (akhlak) yang mulia.

Dunia modern saat ini termasuk di Indonesia telah ditandai dengan gejala kemerosotan akhlak yang berada pada taraf yang menghawatirkan. Kejujuran dan kasih sayang sudah tertutup oleh penyelewengan, penipuan dan saling merugikan, saling mengadu domba dan memfitnah, dan lain sebagainya.

Gejala kemerosotan akhlak dewasa ini bukan saja menimpa kalangan dewasa, tetapi juga menimpa kalangan anak anak. Perilaku yang kurang baik disebabkan oleh h. 10 .

\footnotetext{
${ }^{1}$ Zakiyah Daradjat, Peranan Agama dalam Kesehatan Mental,(Jakarta:Gunung Agung, 1979),
} 
beberapa faktor yang kini mempengaruhi cara berpikir manusia modern. Faktor tersebut menurut Zakiah Daradjat antara lain kebutuhan hidup yang semakin meningkat, rasa individualistis dan egoistis, persaingan dalam hidup, keadaan yang tidak stabil, dan terlepasnya pengetahuan dari agama. ${ }^{2}$

Kondisi krisis ${ }^{3}$ dan dekadensi moral menunjukkan bahwa seluruh pengetahuan agama dan moral yang didapatkan tidak berdampak terhadap perubahan perilaku manusia baik di lingkungan sekolah, ${ }^{4}$ lingkungan keluarga, atau pun lingkungan masyarakat.

Ki Hajar Dewantara (dalam Hasbullah), justru memfokuskan penyelenggaran pendidikan dengan "Tricentra" yang merupakan tempat pergaulan anak didik dan sebagai pusat pendidikan yang amat penting. Tricentra tersebut ialah:

1. Alam keluarga yang membentuk lembaga pendidikan keluarga

2. Alam perguruan yang membentuk lembaga pendidikan sekolah

3. Alam pemuda yang membentuk lembaga pendidikan masyarakat. ${ }^{5}$

Perkembangan ilmu pengetahuan melahirkan berbagai macam dampak terhadap kehidupan manusia dan lingkungannya, di satu sisi mampu membantu dan meringankan beban manusia, namun di sisi lain juga mempunyai andil dalam menghancurkan nilainilai kemanusiaan. Ilmu Barat yang bercorak sekuler melahirkan ilmu pengetahuan yang jauh dari nilai-nilai spritual, moral dan etika. Oleh karena itu Islamisasi ilmu pengetahuan dalam pandangan para pemikir Islam merupakan suatu hal yang mesti dan harus dirumuskan dalam mengatasi krisis masyarakat modern.

\section{B. Rumusan Masalah}

Berdasarkan latar belakang tersebut di atas, maka pokok masalah dalam makalah ini adalah bagaimana islamisasi ilmu pengetahuan kontribusi dalam krisis masyarakat modern?

\section{PEMBAHASAN}

\section{A. Pengertian Islamisasi Ilmu Pengetahuan}

Islamisasi berasal dari akar kata 'Islam" yang secara etimologi berarti tunduk/pasrah dan patuh, sedangkan dari segi terminologi adalah agama yang menganjurkan sikap pasrah kepada Tuhan dalam bentuk yang diajarkan melalui Rasulullah saw. yang berpedoman pada kitab suci Alquran. Islamisasi adalah bermakna

${ }^{2}$ Zakiyah Daradjat "Peranan Agama dalam Kesehatan Mental", h. 10.

${ }^{3}$ Krisis moral yang terjadi di tengah-tengah masyarakat Indonesia antara lain krisis kejujuran, krisis tanggung jawab, tidak berpikir jauh ke depan, krisis disiplin, krisis kebersamaan, dan krisis keadilan. Darmiyati Zuhdi, Pendidikan Karakter (Yogyakarta: UNY Press, 2009), h. 39-40.

4 Zubaedi, "Desain Pendidikan Karakter", h. 2.

5 Hasbullah, Sejarah Pendidikan Islam di Indonesia; Lintasan Sejarah Pertumbuhan dan Perkembangan (Cet. IV; Jakarta; PT. RajaGrafindo Persada, 2001), h. 130. 
pengislaman. ${ }^{6}$ Islamisasi sebagai proses pengislaman tidak hanya diberlakukan terhadap manusia, tetapi juga diberlakukan terhadap hal-hal yang menyangkut hajat orang banyak. Salah satu hal yang menyangkut hajat orang banyak adalah ilmu pengetahuan.

Islamisasi ilmu pengetahuan pada dasarnya adalah suatu respon terhadap krisis masyarakat modern yang disebabkan karena pendidikan Barat yang bertumpu pada suatu sudut pandangan dunia yang lebih berdasar pada paham materialisme. Pendidikan Barat menganggap bahwa pendidikan bukan untuk membuat manusia bijak, tetapi memandang realitas sebagai suatu yang bermakna secara material bagi manusia. Pandangan Barat tersebut yang kemudian menjadi salah satu penyebab munculnya krisis masyarakat modern.

Islamisasi ilmu pengetahuan mencoba mencari akar krisis tersebut di atas, yang diantaranya dapat ditemukan di dalam basis ilmu pengetahuan, dengan mengupayakan pembebasan pengetahuan dari asumsi atau penafsiran Barat terhadap realitas, dan kemudian menggantikannya dengan pandangan dunia Islam.

Selain itu, Islamisasi ilmu pengetahuan juga muncul sebagai reaksi terhadap adanya konsep dikotomi antara agama dan ilmu pengetahuan yang misalnya memandang sifat, metode, struktur sains, dan agama jauh berbeda, atau dapat dikatakan kontrakdiktif. Agama mengasumsikan atau melihat suatu persoalan dari segi normatif, sedangkan sains meneropongnya dari segi objektifnya.

Agama melihat problematika dan solusi melalui petunjuk Tuhan sedangkan sains melalui eksperimen dan rasio manusia. Ajaran agama dan kebenaran ajaran agama diyakini sebagai petunjuk Tuhan, serta kebenaran dinilai mutlak, sedangkan kebenaran sains relatif. Agama banyak berbicara yang gaib sedangkan sains hanya berbicara mengenai hal yang empiris. ${ }^{7}$

Adanya Islamisasi ilmu pengetahuan diharapkan nantinya akan menghasilkan sebuah sains Islam yang didasarkan pada Alquran dan al-Hadits, dimana sains Islam tersebut berbeda dengan sains Barat yang telah berkembang. Adapun perbandingan antara sains Barat dan sains Islam, yaitu: ${ }^{8}$

\begin{tabular}{|l|l|l|}
\hline No & \multicolumn{1}{|c|}{ Sains Barat } & \multicolumn{1}{|c|}{ Sains Islam } \\
\hline 1 & Percaya pada rasionalitas & Percaya pada wahyu \\
\hline 2 & Sains untuk sains & $\begin{array}{l}\text { Sains adalah sarana untuk mendapatkan } \\
\text { keridhoan Allah }\end{array}$ \\
\hline
\end{tabular}

${ }^{6}$ Nurkholis Majid, Islam, Kemodernan dan Keindonesiaan, Cet. XI, (Bandung: Mizan, 1998), h. 47.

7 I.R.Poedjawajatna, Pengantar Ilmu Pengetahuan dan Filsafat Ilmu, (Jakarta: Bina Aksara, 1983), h.62.

${ }^{8}$ Nasim Butt, Sains dan Masyarakat Islam, (Badung: Pustaka Hidayah, 1991), h. 73-76. 


\begin{tabular}{|c|c|c|}
\hline 3 & $\begin{array}{l}\text { Satu-satunya metode atau cara untuk } \\
\text { mengetahui realitas }\end{array}$ & $\begin{array}{l}\text { Banyak metode berlandaskan akal dan } \\
\text { wahyu baik secara objektif dan subjektif }\end{array}$ \\
\hline 4 & $\begin{array}{llr}\text { Netralitas } & \text { emosional } & \text { sebagai } \\
\text { prasyarat } & \text { kunci } & \text { menggapai } \\
\text { rasionalitas } & & \end{array}$ & $\begin{array}{l}\text { Komitmen emosional sangat penting } \\
\text { untuk mengangkat usaha-usaha sains } \\
\text { spiritual maupun sosial }\end{array}$ \\
\hline 5 & $\begin{array}{l}\text { Tidak memihak, ilmuwan hanya } \\
\text { peduli pada produk pengetahuan baru } \\
\text { dan akibat-akibat penggunaannya }\end{array}$ & $\begin{array}{l}\text { Pemihakan pada kebenaran, ilmuan } \\
\text { harus peduli terhadap hasil-hasil dan } \\
\text { akibat-akibat penemuannya secara moral } \\
\text { sebagai bentuk ibadah }\end{array}$ \\
\hline 6 & $\begin{array}{l}\text { Tidak adanya bias, validitas suatu } \\
\text { sains hanya tergantung pada bukti } \\
\text { penerapannya (objektif) bukan } \\
\text { ilmuwan yang menjalankannya } \\
\text { (subjektif) }\end{array}$ & $\begin{array}{l}\text { Adanya subjektivitas, validitas sains } \\
\text { tergantung pada bukti penerapan juga } \\
\text { pada tujuan dan pandangan } \\
\text { ilmuwan yang menjalankannya }\end{array}$ \\
\hline 7 & $\begin{array}{l}\text { Penggantungan pendapat, sains } \\
\text { hanya dibuat atas dasar bukti yang } \\
\text { meyakinkan }\end{array}$ & $\begin{array}{l}\text { Menguji pendapat, sains dibuat atas } \\
\text { dasar bukti yang tidak meyakinkan }\end{array}$ \\
\hline 8 & Netralitas, sains adalah netral & $\begin{array}{l}\text { Orientasi nilai, sains adalah sarat nilai } \\
\text { berupa baik atau buruk juga halal atau } \\
\text { haram }\end{array}$ \\
\hline 9 & $\begin{array}{l}\text { Loyalitas } \quad \text { kelompok, } \\
\text { pengetahuan baru adalah } \\
\text { terpenting dan perlu dijunjung tinggi }\end{array}$ & $\begin{array}{l}\text { Loyalitas pada Tuhan dan makhluk-Nya, } \\
\text { hasil pengetahuan baru adalah cara } \\
\text { memahami ayat-ayat Tuhan dan harus } \\
\text { diarahkan untuk meningkatkan kualitas } \\
\text { ciptaan-Nya }\end{array}$ \\
\hline 10 & $\begin{array}{l}\text { Kebebasan absolute, } \\
\text { pengekangan atau ada } \\
\text { penelitian sains }\end{array}$ & $\begin{array}{l}\text { Manajemen sains adalah sumber yang } \\
\text { tidak terhingga nilainya, sains dikelola } \\
\text { dan direncanakan dengan baik dan harus } \\
\text { dipaksa oleh nilai etika dan moral }\end{array}$ \\
\hline
\end{tabular}

Selanjutnya, pengertian islamisasi ilmu pengetahuan dijelaskan oleh al-Attas, yaitu pembebasan manusia dari tradisi magis, mitologis, animistis, kultur-nasional (yang bertentangan dengan Islam) dan dari belenggu paham sekuler. Selain itu, pembebasan dari kontrol dorongan fisik yang cenderung sekuler dan tidak adil terhadap hakikat diri atau jiwanya, sebab manusia dalam wujud fisiknya cenderung lupa terhadap hakikat dirinya yang sebenarnya, dan berbuat tidak adil terhadapnya. ${ }^{9}$

9 Wan Mohd Nor Wan Daud, The Educational Philosophy and Practice of Syed Muhammad Naquib al-Attas, diterjemahkan oleh Hamid Fahmy dkk, Filsafat dan Praktik Pendidikan Islam Syed M. Naquib al-Attas, (Bandung: Mizan, 1998), h. 341. 
Menurut al-Attas, untuk melakukan islamisasi ilmu pengetahuan perlu melibatkan dua proses yang saling berhubungan. Pertama ialah melakukan proses pemisahan elemen dan konsep kunci yang membentuk kebudayaan dan peradaban Barat, dan kedua, memasukan elemen Islam dan konsep kunci ke dalam setiap cabang ilmu pengetahuan masa kini yang relevan. ${ }^{10}$

Dengan demikian, melalui Islamisasi ilmu pengetahuan, umat Islam akan terbebaskan dari belenggu hal-hal yang bertentangan dengan Islam, sehingga timbul keharmonian dan kedamaian dalam dirinya.

Al-Attas menolak pandangan bahwa islamisasi ilmu bisa tercapai dengan melabelisasi sains dan prinsip Islam atas ilmu sekuler. Usaha yang demikian hanya akan memperburuk keadaan dan tidak mempunyai manfaat selama "virus"nya masih berada dalam tubuh ilmu itu sendiri, sehingga ilmu yang dihasilkan pun jadi mengambang karena Islam bukan dan sekuler pun juga bukan. Tujuan dari islamisasi tersebut adalah untuk melindungi umat Islam dari ilmu yang sudah tercemar, menyesatkan, dan menimbulkan kekeliruan. Islamisasi ilmu dimaksudkan untuk mengembangkan kepribadian muslim yang sebenarnya sehingga menambah keimanannya kepada Allah, dan dengan islamisasi tersebut akan lahir keamanan, kebaikan, keadilan dan kekuatan iman. ${ }^{11}$

Secara umum, Islamisasi ilmu tersebut dimaksudkan untuk memberikan respon positif terhadap realitas ilmu pengetahuan modern yang sekularistik dan Islam yang "terlalu" religius, dalam model pengetahuan baru yang utuh dan integral tanpa pemisahan di antaranya.

Selain pengertian islamisasi ilmu pengetahuan tersebut di atas, Osman Bakar mengungkapkan bahwa islamisasi ilmu pengetahuan adalah sebuah program yang berupaya memecahkan masalah yang timbul karena pertemuan antara Islam dengan sains modern sebelumnya. ${ }^{12}$

Keselarasan antara Islam dan sains modern memberikan penekanan tentang sejauhmana sains dapat bermanfaat bagi umat Islam. M. Zainuddin menyimpulkan bahwa islamisasi pengetahuan pada dasarnya adalah upaya pembebasan pengetahuan dari asumsi Barat terhadap realitas dan kemudian menggantikannya dengan world viewnya sendiri (Islam). ${ }^{13}$

Pengertian Islamisasi pengetahuan diatas dapat disimpulkan bahwa islamisasi dilakukan dalam upaya membangun kembali semangat umat Islam dalam mengembangkan ilmu pengetahuan melalui kebebasan penalaran intelektual dan kajian rasional - empirik dan filosofis dengan tetap merujuk kepada kandungan Alquran dan

\footnotetext{
${ }^{10}$ Wan Mohd Nor Wan Daud "The Educational Philosophy and Practice", h. 345.

11 Ibid.

12 Osman Bakar, Tauhid dan Sains, (Bandung: Pustaka Hidayah, 1994), h. 233.

${ }^{13}$ M. Zainuddin, Filsafat Ilmu: Persfektif Pemikian Islam, (Malang: Bayu Media, 2003), h. 160.
} 
Sunnah Nabi. Dengan demikan, umat Islam akan bangkit dan maju kembali menyusul ketertinggalan dari umat lain, khususnya Barat.

\section{B. Islamisasi Ilmu Pengetahuan kontribusi dalam mengatasi masyarakat modern}

Islam pada periode awal, menunjukkan pendidikan Islam mencapai puncak kemajuan yang sangat pesat (zaman keemasan Islam) mengunguli Barat. Pencapaian masa keemasan didasari oleh tiga hal, yaitu :

1. Umat Islam memberikan ruang yang cukup besar terhadap pengembangan pemikiran ilmu pengetahuan.

2. Studi keislaman selalu dilandasi nilai moral.

3. Umat Islam tidak mendikotomikan ilmu pengetahuan.

Pada perkembangan selanjutnya, Islam mengalami kemunduran yang diantaranya disebabkan oleh adanya pengkotakan ilmu, yaitu ilmu Islam dan ilmu Barat yang dianggap kafir. Sementara itu, Barat mulai mengkaji dan meneliti ilmu pengetahuan karya umat Islam, mengkaji secara serius kehidupan masyarakat Islam, dan juga mempelajari kebudayaan Islam itu sendiri yang membawa pada kemajuan Barat atau yang dikenal dengan renaisans.

Sejak dekade 70-an, diskusi islamisasi mulai mengemuka di kalangan ilmuan. Pada saat itu, kondisi ilmu pengetahuan Barat menguasai dunia yang bermuatan tanpa nilai (bebas nilai) dan lebih cenderung kepada sesuatu yang material saja. Para pemikir dikalangan ummat Islam menyadari bahwa ilmu pengetahuan buatan manusia tidak boleh bebas terpakai dan menguasai, dalam arti produk nilai manusia tetapi harus bernilai produk Tuhan.

Oleh karena itu, lahirlah islamisasi ilmu pengetahuan dari sebuah korelasi terhadap ilmu-ilmu modern yang cenderung bebas dari nilai dan terlepas dari tuntunan wahyu. ${ }^{14}$ Tokoh atau penggagas islamisasi ilmu pengetahuan di antaranya Ismail alfaruqy, Syech Muhammad Naquib al-Attas, dan Ziauddin Sardar. Lahirnya gagasan Islamisasi ilmu pengetahuan didasarkan pada pandangan bahwa ilmu pengetahuan produk modern tidak berhasil membawa manusia pada cita-cita ilmu itu sendiri. Hal tersebut disebabkan karena ilmu terlepas dari akar Ilahy dan dikosongkan dari pertimbangan nilai. ${ }^{15}$ Pada perkembangan selanjutnya, para pemikir muslim dan lembaga Islam melahirkan pikiran-pikiran Islamisasi sebagai literatur filsafat ilmu Islam dan islamiasi pengetahuan. ${ }^{16}$

Ada beberapa langkah yang dilakukan dalam rangka merealisasikan islamisasi ilmu pengetahuan kontribusi dalam mengatasi krisis masyarakat modern, yaitu:

${ }^{14}$ Laura Veccia Vaglieri, Apologia Dell Islamismo diterjemahkan oleh Ahmad Daudy dengan judul Apologi Islam, (Jakarta : Bulan Bintang, 1983), h. 80.

${ }^{15}$ Muhammad Zain, Proyek Islamisasi Ilmu Pengetahuan Syech Muhammad Naquib al-Attas, (Yogyakarta : LESISKA, 2001), h. 1.

${ }^{16}$ Juhaya S. Praja, Filsafat Ilmu, (Jakarta : Teraju, 2002), h. 222-224 
1). Menguasai dan mahir dalam disiplin ilmu pengetahuan modern

Individu Islam terutama sarjana yang beragama Islam harus menguasai ilmu pengetahuan modern yang berkembang saat ini, baik prinsip, konsep, metodologi, masalah, dan tema. ${ }^{17}$ Pentingnya ilmuan muslim menguasai ilmu pengetahuan modern agar dapat menemukan suatu konsep baru yang memiliki konsep dan prinsip tauhid.

2). Tinjauan disiplin ilmu pengetahuan

Langkah ini diupayakan untuk mengetahui disiplin ilmu pengetahuan yang berkembang, yang kemudian dikaji dalam bentuk karya ilmiah dan menuliskan tentang asal-usul, perkembangan dan metodologinya, serta keluasan cakrawala visi dan sumbangan pemikiran para tokoh utamanya. Salah satu syarat proses pengkajian ini adalah rujukannya harus bernilai yang berurutan dari buku dan artikel primer, ${ }^{18}$ sehingga secara tidak langsung akan ditemukan sumber asli ilmu pengetahuan tersebut.

3). Menguasai warisan Islam

Gagasan islamisasi ilmu pengatahuan menjadi kurang bermakna apabila tidak dikaitkan masalah warisan Islam yang menyumbangkan ilmu pengetahuan yang sangat besar. Namun demikian, sumbangan intelektual muslim tradisional tentang disiplin ilmu pengetahuan modern tidak mudah diperoleh, dibaca, dan dipahami oleh seorang intelektual muslim saat ini, dengan alasan: ${ }^{19}$

a. Ilmu pengetahuan modern tidak terdapat padanannya dalam khazanah intelektual Islam.

b. Para sarjana muslim terutama yang mendapatkan pendidikan Barat (sekuler) sering gagal memahami khazanah warisan Islam yang menganggap warisan Islam tidak memiliki kekuatan apapun terhadap disiplin ilmu yang dipelajarinya.

c. Para sarjana muslim tidak memiliki waktu atau usaha untuk meneliti khazanah warisan Islam yang amat kaya dan luas.

Sebaliknya, para sarjana muslim yang dididik secara tradisional sebagai otoritas pemilik khazanah warisan Islam tidak dapat memecahkan maupun menetapkan keterkaitan warisan tersebut dengan disiplin ilmu pengetahuan modern. Oleh karena itu, perlu diperkenalkan ilmu pengetahuan modern kepada sarjana pewaris ilmu pengetahuan Islam tradisional begitu pula sebaliknya. Selanjutnya, warisan Islam tersebut dianalisis berdasarkan latar belakang sejarah dan kaitan antara masalah yang dibahas dengan berbagai bidang kehidupan manusia secara jelas.

4). Penentuan penyesuaian Islam terhadap disiplin ilmu pengetahuan.

Ketiga langkah yang telah disebutkan di atas perlu ditekankan bahwa disiplin ilmu pengetahuan modern beserta metodologi-metodologi dasar, prinsip, masalah, tujuan dan

\footnotetext{
${ }^{17}$ IIIT, Islamisasi Ilmu Pengetahuan, (Jakarta: Lontar Utama, 2000), h. 75.

${ }^{18}$ IIIT "Islamisasi Ilmu Pengetahuan", h. 76.

${ }^{19}$ IIIT "Islamisasi Ilmu Pengetahuan", h. 77.
} 
harapan, kejayaan dan batasannya, semuanya harus dikaitkan kepada warisan Islam, ${ }^{20}$ serta disesuaikan dengan Islam.

5). Penilaian kritis terhadap disiplin ilmu pengetahuan modern

Hubungan antara Islam dan ilmu pengetahuan yang memerlukan penilaian kritis merupakan suatu langkah utama dalam islamisasi ilmu pengetahuan agar disiplin yang dihasilkan tidak ada kekurangan dan kemustahilan, sebaliknya harus ada kesesuaian dengan ketetapan dasar dengan Islam. ${ }^{21}$

6). Penilaian kritis terhadap warisan Islam

Warisan Islam adalah bukan Alquran dan Sunnah melainkan karya manusia yang berdasarkan kedua sumber tersebut. Penilaian kritis terhadap karya manusia tidak lagi memainkan peran yang dinamis dalam kehidupan umat Islam, ${ }^{22}$ sehingga perlu pengkajian secara kritis agar warisan tersebut tetap eksis bukan diselewengkan.

7). Kajian masalah utama umat Islam

Umat Islam pada saat sekarang mengahadapi berbagai masalah baik dari segi politik, sosial, ekonomi, intelektual, kebudayaan, moral, dan spiritual. Hal ini memerlukan perenungan dan langkah yang nyata untuk keluar dari semua permasalahan tersebut sehingga diperlukan kajian yang serius dan mendalam. ${ }^{23}$ Oleh karena itu, solusi permasalahan tersebut seharusnya dapat diketahui sehingga jalan untuk melaksanakan gagasan islamisasi ilmu pengetahuan dapat terwujud.

8). Melakukan analisis kreatif dan sintesis

Setelah memahami, menguasai disiplin ilmu pengetahuan modern dan ilmu pengetahuan Islam tradisional, menilai kekuatan dan kelemahan keduanya, menentukan kaitan Islam dengan bidang pemikiran ilmiah tertentu pada disiplin ilmu pengetahuan modern; maka saatnya untuk membentuk sebuah lompatan yang kreatif yang bernafaskan Islam. Metodo baru perlu dicetuskan untuk mengembalikan supremasi Islam di dunia. Jurang pemisah antara ilmu Islam tradisional dengan ilmu pengetahuan modern dapat dijembatani dengan sebuah sintesa kreatif antar keduanya. ${ }^{24}$

Warisan Islam harus berkesinambungan dengan pencapaian ilmu modern, dan harus menggerakkan batasan ilmu pengetahuan ke arah yang lebih jauh dari apa yang telah digambarkan oleh disiplin ilmu pengetahuan modern.

9). Membentuk kembali disiplin ilmu modern dalam kerangka kerja Islam dengan menulis kembali "buku teks" yang memuat visi baru tentang pengertian Islam serta

\footnotetext{
${ }^{20}$ IIIT “Islamisasi Ilmu Pengetahuan”, h. 79.

${ }^{21}$ IIIT “Islamisasi Ilmu Pengetahuan”, h. 81.

${ }^{22}$ IIIT “Islamisasi Ilmu Pengetahuan”, h. 82.

${ }^{23}$ IIIT “Islamisasi Ilmu Pengetahuan”, h. 84.

${ }^{24}$ IIIT “Islamisasi Ilmu Pengetahuan”, h. 86-87.
} 
pilihan kreatif sebagai realisasi gagasan islamisasi ilmu pengetahuan. Sejumlah buku teks dibutuhkan agar kebutuhan dasar kaum muslimin akan intelektualitas dapat terpenuhi. ${ }^{25}$ Dengan demikian, secara tidak langsung ilmuwan muslim dituntut untuk selalu menghasilkan teori dan ide baru tentang ilmu pengetahuan yang berbasis Islam.

10). Pendistribusian ilmu yang telah diIslamkan

Hasil karya umat Islam akan menjadi sia-sia jika sebuah ilmu hanya disimpan sebatas koleksi pribadi, atau hanya diketahui oleh kalangan tertentu saja, atau hanya digunakan di lingkungan pendidikan atau negeri mereka saja. Apapun yang dihasilkan oleh ilmuwan muslim adalah untuk mendapatkan keridhoan Allah yang merupakan milik seluruh umat Islam, karena hasil karya tersebut untuk membangkitkan, memberi petunjuk umat Islam dan untuk menyebarkan visi Islam. ${ }^{26}$ Oleh karena itu hasil karya tersebut harus terbuka untuk umum, dan hasil kerangka kerja Islam tersebut harus diberikan secara resmi kepada pusat pendidikan tinggi dunia Islam dengan pertimbangan menjadi bacaan wajib.

Beberapa langkah tersebut di atas merupakan upaya agar umat Islam dapat berjaya kembali seperti apa yang telah tersurat di dalam sejarah. Zaman keemasan Islam akan kembali bersinar dengan usaha maksimal yang dilakukan oleh umat Islam itu sendiri.

\section{PENUTUP}

\section{A. Kesimpulan}

Dari uraian tersebut diatas penulis berkesimpulan bahwa islamisasi ilmu pengetahuan adalah usaha atau upaya yang dilakukan untuk membebaskan ilmu pengetahuan dari asumsi Barat dan menggantikannya dengan merujuk kepada kandungan Alquran dan Sunnah Nabi.

Beberapa langkah yang dilakukan untuk merealisasikan islamisasi ilmu pengetahuan dalam rangka mengatasi krisis masyarakat modern, di antaranya adalah menguasai ilmu-ilmu pengetahuan modern dan menguasi kembali warisan Islam. Kemudian, perlu pengkajian, diteliti, dan dikritisi agar terpisah ilmu pengetahuan yang bersifat sekuler dan atheis. Selanjutnya, diharapkan muncul ilmu-ilmu pengetahuan baru yang berparadigma Islam.

\section{B. Implikasi}

Islamisasi ilmu pengetahuan selayaknya tetap diperjuangkan dan dipertahankan. Upaya tersebut dilakukan dengan tetap mempertahankan nilai ajaran Islam yang murni tanpa diracuni oleh unsur yang lain.

\footnotetext{
${ }^{25}$ IIIT “Islamisasi Ilmu Pengetahuan”, h. 88.

${ }^{26}$ IIIT “Islamisasi Ilmu Pengetahuan”, h. 88.
} 


\section{DAFTAR PUSTAKA}

Arifin, HM. Ilmu Pendidikan Islam: Tinjauan Teoretis dan Praktis Berdasarkan Pendekatan Interdisipliner. Jakarta: Bumi Aksara, 2006.

Bakar, Osman. Tauhid dan Sains. Bandung: Pustaka Hidayah, 1994.

Butt, Nasim. Sains dan Masyarakat Islam. Badung: Pustaka Hidayah, 1991.

Daradjat, Zakiyah. Peranan Agama Dalam Kesehatan Mental. Jakarta: Gunung Agung, 1979.

IIIT. Islamisasi Ilmu Pengetahuan. Jakarta: Lontar Utama, 2000.

Majid, Nurkhalis. Islam, Kemodernan dan Keindonesiaan, Cet. XI. Bandung : Mizan, 1998), h. 47

Masnur M., Pendidikan Karakter: Menjawab Tantangan Krisis Multidimensional. Jakarta: Bumi Aksara, 2011.

Poedjawajatna, I.R. Pengantar Ilmu Pengetahuan dan Filsafat Ilmu. Jakarta: Bina Aksara, 1983.

Praja, Juhaya S. Filsafat Ilmu. Jakarta : Teraju, 2002.

Vaglieri, Laura Veccia. Apologia Dell Islamismo diterjemahkan oleh Ahmad Daudy dengan judul Apologi Islam. Jakarta : Bulan Bintang, 1983.

Wan Daud, Mohd Nor. The Educational Philosophy and Practice of Syed Muhammad Naquib al-Attas, diterjemahkan oleh Hamid Fahmy dkk, Filsafat dan Praktik Pendidikan Islam Syed M. Naquib al-Attas. Bandung: Mizan, 1998.

Zain, Muhammad. Proyek Islamisasi Ilmu Pengetahuan Syech Muhammad Naquib alAttas. Yogyakarta : LESISKA, 2001.

Zainuddin, M. Filsafat Ilmu: Persfektif Pemikian Islam. Malang: Bayu Media, 2003. 